\title{
The preaching of the Greek church fathers
}

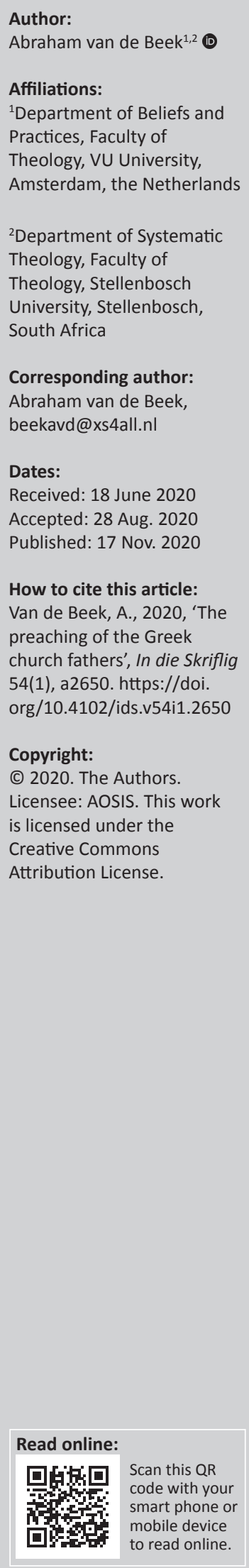

This article deals with the preaching of the Greek church fathers. Genres, themes and hermeneutics are discussed. It appears that not only the biblical text, but also historical events are considered as messages from God and have to be interpreted in order to understand their meaning. A remarkable paradigm shift occurred in the 4 th century when the church became a dominant cultural and political factor. In the early period, the preaching focused on Christ, glorious in his suffering. After the transformation under Constantine, themes of worldview and even submission to the emperor became the subject of preaching. Preaching, which supported existing political powers, replaced the early Christian view of life as strangers on earth. In the last section, the relevance of this for preaching in the 21st century is discussed.

Keywords: preaching; Greek church fathers; Christology; context; paradigm.

\section{Introduction}

The church fathers are at present receiving more attention than has been the case for a long time. Now that the Christian faith in the Western world is under pressure, we notice a large variety of groups and communities seeking new expressions for their faith. Theologians are looking for relevant approaches, on the one hand, and searching for the means of orientation, on the other. The church fathers are of eminent importance in this regard. It is amazing that, for instance, in the Netherlands, where secularisation is even accelerating, translations of the writings of church fathers are published frequently; not only the works of Augustine, but also Origenes's On the Principles, and other Greek fathers. Symposia on the church fathers are overbooked, lecture series frequented, and articles in newspapers avidly read.

This article is devoted to the sermons of the Greek fathers. How did they preach? Is their way of preaching indeed relevant for today? The sermons are from the period of the second to the beginning of the 5th century $\mathrm{AD}$, that is, from the earliest preserved sermons to the time of the consolidation of the Christian empire of the Byzantine emperors. The context of preaching changed radically during this period: from the small, often persecuted communities to the dominant culture under the rule of protecting emperors. An analysis of the influence of this shifting context in early Christianity on preaching is of new interest now that the corpus christianum has declined.

\section{Selection}

When we investigate the sermons of the Greek fathers, we must first consider that only a very small part of the innumerable sermons of the first centuries have been preserved. Most of them were lost. Moreover, most of them were never written down. So, we only have a very small selection. This, however, is not a random selection.

A sermon was often saved because of its special appeal to the hearers, that is, the people of that time. It might very well be that many sermons, which would have appealed to people of the $21 \mathrm{st}$ century, have been lost, because they did not appeal very much to the Christians of that time.

Moreover, it was not only a matter of writing down a sermon, but also of copying it - which begs the question: Which of the written sermons were saved by later generations? These sermons would have had to be worth the effort and cost of making copies. Thus, not only the content of sermons was relevant for their selection for later generations, but also who delivered them, or to whom were they ascribed. Naturally, sermons of authoritative figures would have received priority.

The choices made during the research for this article were also guided by personal interest - in this case of myself. Which sermons were selected as more or less relevant? What emphases were 
highlighted? As research does not happen in a void but in a community of scholars, their influence will also be apparent in this article. So we can conclude that a discourse about sermons of the Greek fathers does not only reveal something about their hermeneutics, but also about their reception history, that is, the history of the hermeneutics by which ancient texts have been valued, selected and interpreted. The final steps in this process, the selection and focus of modern authors, can be reconstructed rather well, because not only the positive choices are available, but also the rejected or neglected writings or sections. The earlier steps in this process, however, can only be reconstructed from external evidence. Generally, it is not possible to trace why sermons have been lost, or why sermons were never written down, because their content is unknown to us. Our only positive conclusion is that the preserved sermons appealed to their own time and were relevant enough to be copied and preserved for later generations. This selection reflects the hermeneutical position of the first and of later generations.

In the selection for this article, different genres of sermons, main themes of focus, chronological periods, and variety in hermeneutic approaches have been taken into account.

\section{Genres}

Sermons in the Early Church do not all have the same character. This affects the hermeneutical processes. The main distinction is between homilies in a lectio continua about Bible books or parts thereof, and sermons about themes or on specific occasions.

Homilies on parts of the Bible in a lectio continua were usually given at the beginning of each day (Sieben 1991:14). The content of these homilies was determined by the biblical text. The interpretation of this text, however, depended very much on the context and theological position of the preacher. By answering the question of what this text is about, and what its significance for us as hearers is, meaning is attributed to the text. Thus, the focus is on the text which must be interpreted, and the hermeneutic circle rotates between the poles of text and hearer.

Sermons which were not related to the lectio continua had a greater variety. This is especially the case with sermons that were given on the occasion of particular events. In these sermons, it is not a Bible verse that determined the content, but an external event, such as drought (Basilius, Homilia dicta tempore famis et siccitatis, MPG 31:303-328) or a fire (Basilius, Quod rebus mundanis adhaerendum non sit, et de incendio extra Ecclesiam facto, MPG 31:539-564).

A characteristic example of such occasional preaching is a sermon of John Chrysostomos (Homilia post terrae motu, MPG 50:713-716) about an earthquake which destroyed Antioch. This is not about the interpretation of Bible verses, but about the interpretation of a natural calamity. It is remarkable that Chrysostomos considered this as an act of God. It is not a horrible natural disaster after which the pastor proclaims comfort in God's name, but it is something that God allowed to happen to him and his fellow citizens. The natural event is dealt with as a text which God has given to us and which we must interpret. What is God's message to us through this catastrophe? Here, the hermeneutical poles are not the text of the Bible and the interpreter, but natural events and interpreter. However, in both cases it is about a message from God. ${ }^{1}$

A third category is that of sermons on Christian festivals. The events to which the festivals referred, were decisive for the preaching on such days. Because the festivals are about the core issues of Christian faith, the focus is on the themes of the Creed. Here, the poles are the Creed and the interpreter and, as the meaning of the Creed is standardised by councils and tradition, the preacher did not have much room for his own interpretation. Thus, subtle nuances become even more interesting.

The last category is that of sermons on texts and subjects of free choice. These come close to the daily homilies, but because of the free text choice, the interpreter has much more room. He does not have to deal with a prescribed text, and he can give his own message related to a selfchosen text.

\section{Christian life}

Many sermons of the Greek fathers are exhortations to Christian life. They follow the parenesis of the New Testament. Christians are different from pagans and their lives must display this. The famous fifth chapter of To Diognetus sketches this ideal (Thierry 1964:16). However, reality often refuted this ideal. In the earliest preserved sermon after the New Testament, II Clement ([Pseudo-] Clemens of Rome, Epistola II, MPG 1:329-348), the audience is admonished that, although the Christian message is wonderful and attractive, the real way of Christians' lifes is repulsive to other people:

\footnotetext{
... for, whenever they hear from us that God says: 'No thank have ye, if you love them which love you, but you have thank, if you love your enemies and them which hate you' - whenever they hear these words, they marvel at the surpassing measure of their goodness; but when they see, that not only do we not love those who hate, but that we love not even those who love, they laugh us to scorn, and the name is blasphemed. ([Pseudo-] Clemens of Rome, Epistola II [II Clement], 13.3, MPG 1:329-348; transl. Keith 1896)
}

They are hearers of the word, but the message appears to have evaporated as soon as they left the assembly. It has no

1.Up to modernity, it was usual to consider natural events as an act of God with a message for men. Compare Confessio Belgica 1,2: 'We know God by two means: first, by the creation, preservation, and government of the universe, since that universe is before our eyes like a beautiful book in which all creatures, great and small, are as letters to make us ponder the invisible things of God Second God small, are as letters to make us ponder the invisible things of God .... Second, God makes himself known to us more clearly by his holy and divine Word', because the Enlightenment nature is regarded as a neutral domain. This did not seriously affect the preaching of the church before the second half of the 20th century. Presently, Western people hardly accept this view. When the attack of $9 / 11$ or the tsunami of 2004 is interpreted as a punishment by God, furious reactions arise. People, most of all Christian people, can no longer accept such a God. Obviously, they are not aware how deep such interpretations are rooted in the tradition of the church. 
impact on their lives ([Pseudo-] Clemens of Rome, Epistola II [II Clement], 17.3, MPG 1:329-348). Not much has changed from the middle of the 2nd century to the beginning of the 21 st century. Even a letter as early as that of James warns not only to listen to the word, but also to do it (Ja 1:19ff). The poor are not helped by a good message only (Ja 2:14-16). So, it is wise to not draw ideal images of early Christianity based on the good message of which the writings bear witness. Reality was stubborn, even then.

An important theme is the use of money. The authors of the New Testament already wrote very critically about riches (Mt 6:24; 13:22; Lk 6:24; 8:14; 16:13-15; 1 Tm 6:9, 17; Ja 1:10ff.). According to the Gospels, Jesus himself opposes those who adhere to their wealth. He opposes wealth in his parables: the rich fool (Lk 12:15-21), and the rich man and the poor Lazarus (Lk 16:19-31), as well as in the story of the rich young man (Mt 19:16-26; Mk 10:17-27; Lk 18:18-27). It is difficult for a rich person to enter the kingdom of God (Mt 19:23f; Mk 10:24f; Lk 18:24ff.). Some decades later, Jesus' brother, James (4:1-6), holds a philippic against the rich people in the congregation. The risk of wealth continues to be an important topic in Christian literature during the following centuries. Clement of Alexandria discusses extensively the question whether a rich man can be saved (Clemens of Alexandrië, Quis dives salvetur, MPG 9:603-652).

After the transformation under Constantine, the theme became even more urgent. Christians were then on the positive side of the social balance. They had obtained good positions and many good opportunities. By the end of the 4th century, Basil the Great devoted a sermon to the danger of wealth (Basilius, Homilia in Divites, MPG 31:277-304). John Chrysostomos does even more so. Rooted in the tradition of a serving and suffering church, he could not cope with the self-enrichment of people around him. In his sermon after the devastating earthquake in Antioch (Homilia post terrae motu, MPG 50:713-716), Chrysostomos interprets this event as a correction of social positions by God. When man promotes social inequality, God makes everything equal. The rich have lost everything and so they are now on the same level with the poor. So, the earthquake was a blessing of the Lord to correct human greed.

The earthquake did not only serve as a correction of the wealthy in the congregation. It was also a punishment for wrongdoing. What should the reaction be after such a disaster? For Chrysostomos, the answer is clear: When God chastises us in such a manner, it can only be to call us to conversion. Fortunately, Chrysostomos (Homilia post terrae motu, MPG 50:715) already notices the effects: choirs singing Christian hymns have replaced the licentious life in the city.

Both in the homilies and in the sermons, Christian life is a connecting theme in the preaching of the church fathers. In the early period, it aimed to instil perseverance, but the focus was more on distancing from pagan uses and ways of life: licentiousness, alcohol abuse, hatred, quarrels and sexual abuses. Christians were called to demonstrate the Christian way of life through practical love, care and responsibility for each other, for the poor and the weak in society, tolerance and non-violence. Once again: the fact that this was proclaimed, did not mean that reality reflected this calling; rather the opposite: it had to be continuously impressed on the Christians. Nevertheless, it is also clear that the parenesis was not totally without effect. If that had been the case, apologists would not have been able to plead for Christians with reference to their way of life. So, the preaching in interaction with the apologetic writings provides a view into the dynamic practice of the Christian community in its earliest centuries.

For the early fathers, Christian ethics was not an alternative on the market of worldviews, human traditions, and their corresponding ways of life. It was not about the application of a Christian philosophy as a model for society. Christian life is founded on the new reality, which dawned with Christ. Ethics did not arise from his teaching, but from his identity and from the liberating reality, which came through his death and resurrection. Because people participate in Christ, they participate in his life, and this becomes visible in their actions. The Christian lifestyle is not separately available. It exists only in Christ as the expression of the divine life that he bestowed.

II Clement ([Pseudo-] Clemens of Rome, Epistola II, MPG 1:329-348) is paradigmatic in this regard. The sermon starts laconically with: 'Brethren, it is fitting that you should think of Jesus Christ as of God' ([Pseudo-] Clemens of Rome, Epistola II [II Clement], 1.1, MPG 1:329-348). This is followed by a short exposition about the grace of Christ in his suffering for us. Because this God is our God, our life reflects his dedication and servantship, and we are totally dedicated to him (Pseudo-) Clemens of Rome, Epistola II (II Clement), 1.15ff., MPG 1:329-348). It is this God who judges our lives ([Pseudo-] Clemens of Rome, Epistola II [II Clement], 1.1, MPG 1:329-348) and, in imitation of his life of service, we will be judged (1.15ff.).

For the early Greek fathers, Christian ethics was not an option without being in Christ who, being God himself, has the final judgement over us, and who, in his suffering and servantship, in his divinity which became visible in his suffering humanity, is the paradigm of the good. This is the focus of the very first sermon, which the Christian tradition has preserved, and this approach is basic for the centuries that followed. In the Alexandrian tradition, Cyrillus of Alexandria (Homiliae Paschales, 17, MPG 77:768-790) keeps to the absolute unity of God and man in the one person of Christ who is God and who suffered in the human flesh, and the absolute unity of the Christians with him, suffering and serving in the world and sharing his eternal life. ${ }^{2}$ Thus, Christian ethics developed in this radical Christological perspective. Cyril blames Nestorius for propagating an independent humanity and thus an independent ethics not embedded in the divine life of Christ. Consequently, we must save ourselves.

2.Formally this is an Easter letter, but its character and content are like a sermon. 


\section{Allegory}

Not only ethics is viewed in Christological perspective. In the sermons of the Greek fathers, everything is considered in the ardour of God's coming and acting in Christ. Christ's coming defines their exegesis and their preaching. This paradigm lends a specific character to their interpretation of Scripture. This is most clear in their series of homilies. Because of the lectio continua, the preacher is urged to think about the meaning of the specific text for the hearers from the perspective of Christ. New Testament texts do not cause many problems, as it deals explicitly with the coming of Christ. More exegetical ingenuity is required for Old Testament readings. Origenes certainly is the champion in this regard. He sets the tone immediately in the first homily on the book Genesis, the very first verse of the Bible:

... in the beginning God created heaven and earth. What is the beginning of all things except our Lord and Savior of all, Jesus Christ, the first born of all creatures? (Origenes, Homiliae in Genesin, 1; transl. Heine 2002)

Christ is de archè of all and therefore everything must be seen from his perspective.

Because the Old Testament is not literally about Jesus, a literal reading of the Old Testament is not sufficient. Consequently, Origenes comes to his allegorical interpretation. He enunciates the theory of his exegesis in the fourth book of his On the Principles, but in his sermons, he continually explains that one cannot comply with Christian teaching without allegorical exegesis. Even if one wished to do so, Scripture itself prohibits a strictly literal reading, to save us from the pitfall of a mere historical interest without religious meaning (Origenes, De principiis, IV.9; IV.16; IV.18). Origenes basically explains this in a sermon about the midwives in Egypt. Pharaoh orders them to kill all boys and to allow the girls to live. Then the Bible states that the women disobeyed Pharaoh's order. According to Origenes (Homiliae in Exodum, 2.2, MPG 12:307), this cannot be taken literally, for this would mean that they let all the boys live and killed all the girls. After all, Pharaoh's commandment was twofold. One may find this casuistic, but Origenes wants to make it clear that reading always implies interpretation. His listeners must know this. These listeners have gathered to be strengthened in faith. Therefore, even a less literal, but nonetheless historical reading is not interesting to them. They did not come for a lecture about ancient Egyptian history. They came to hear the Word of God. The historical correctness of the texts does not interest them. Much might have happened as it was written, but that is not what preaching is about. The proclamation of the Word is about its significance for the hearers. What does it mean that Pharaoh perished, and Israel was liberated? What is Pharaoh in our days? And what is God's liberation for us? The text explains what God means to human beings, and it does so in the form of a historical narrative, but we must well understand that this narrative has a deeper meaning. Otherwise it would be irrelevant, and we may regard it as useless information and leave it at that.

Allegorical exegesis certainly does not lead to arbitrariness with Origenes. He has a clear hermeneutical key, exactly in order to avoid arbitrariness and irrelevance. His key is that everything must be understood according to the Logos. For him, the Logos is not neutral reason, but the person of Christ. Christ is the Logos according to whom the whole Scripture, also the Old Testament, should be interpreted. Christ is not the general reason of being, but the divine Logos expressed in texts consisting in letters and in narratives of events which may be historical or not. So, everything must be interpreted according to the Logos who is Christ, who appeared in this world and who is present in the church. Therefore, Christ cannot be interpreted randomly, but only in the community of the church. The exegesis is borne by the teaching of the church (Origenes, De principiis, I.3.1; II.11.3; IV.1; Contra Celsum, II.2; Heither 2008:44, 50). So, the Christological Creed is the key to understand texts - for Origenes this means any biblical text.

\section{Preaching about Christ}

Since early Christianity, Christ is the key to understand biblical texts and it is no wonder that many sermons are explicitly about him. Of course, this is the case with sermons on the great festivals such as Epiphany and Easter. ${ }^{3}$ However, many other sermons are also specifically about Christ. ${ }^{4}$ These often have a hymnal character or another form to express the exaltation of Christ in his loving submission. A good example of this is a beautiful sermon by (Pseudo-) Gregorius Thaumaturgus (In Sancta Theophania, sive de Christi baptismo, MPG 10:1177-1189) about the baptism of Jesus in the Jordan. ${ }^{5}$ In this sermon, John the Baptist's words to Jesus become an extended monologue in which he sings of the exaltedness of Christ and also gives the reason for his refusal to baptise Jesus. This is followed by a responding monologue of Jesus in which he explains his willingness to submit unto death on behalf of humankind: for being submerged into the water, he becomes one with them in death for their salvation. These words of Jesus are confirmed by a short statement of the Father and followed by the response of the congregation with the final Amen.

The baptism of Jesus was a cherished subject in early Christian preaching. This is the theme of one of the finest sermons in Greek patristics. This sermon is ascribed to (Pseudo-?) Hippolytus and is known as the 'Sermon on the festival of Epiphany' (Sermo in Sancta Theophania, MPG

3.The oldest conserved sermon for a festival is the famous Easter sermon of Melito of Sardis (Lohse 1958)

4.A fine example about the praise of Jesus is a sermon about the triumphal entry of Jesus into Jerusalem (Pseudo-) Methodius, Oratio in ramos palmarum, MPG 18:383-398) which was incorrectly ascribed to Methodius (Bardenhewer 1914:351).

5.The sermon is generally regarded as being from a later time (4th-6th century), thus several possible authors are mentioned; see Bardenhewer 1914:332, who himself proposes Gregory of Antioch (late 6th century) as the author. 
10:851-862). ${ }^{6}$ In this sermon, miscellaneous symbolic motives related to baptism are intertwined, displaying the contrast between the inexpressible exaltedness of Christ and his submersion into the insignificant little river.

The church fathers liked to point out contrasts displaying expressively the paradox between the exaltedness and the humiliation of Christ as is clear in a sermon of Alexander of Alexandria (Sermo de anima et corpore deque passione domini, 5, MPG 18):

\begin{abstract}
... behold, you sons of men! Behold, all you people, these new wonders! They suspended Him on the tree, He who stretches out the earth; they transfixed Him with nails, He who laid firm the foundation of the world; they circumscribed Him, He who circumscribed the heavens; they bound Him, He who absolves sinners; they gave Him vinegar to drink, He who has made them to drink of righteousness; they fed Him with gall, He who has offered them the Bread of Life; they caused corruption to come upon His hands and feet, He who healed their hands and feet; they violently closed His eyes, He who restored sight to them; they gave Him over to the tomb, He who raised their dead to life both in the time before His Passion and also while He was hanging on the tree. (p. 598; transl. Hawkins 1886)
\end{abstract}

The Christological focus is often expressed with reference to the Christological debates in the Early Church. Dogmas and heretics are mentioned explicitly. Of course, this happened most frequently in the times of the great councils, as in the sermons of Cyrillus of Alexandria (Homiliae diversae, MPG 77:981-1009) when he was in Ephesus for the council in 431.

It is remarkable that sermons, which are ascribed to preNicene fathers, but are of a later date according to critical research, are always about the exaltedness of Christ in his humiliation. If these sermons are indeed later, then those who ascribed them to earlier theologians were obviously convinced that such sermons were typical of the earlier period. ${ }^{8}$ Sermons from the 2 nd and 3rd century of which the dates are undisputed, are rare. Apart from the homilies of Origenes, only a few such sermons remain.

\section{A paradigm shift}

After the transformation under Constantine, a change also took place in the sermons, especially in the Greek-speaking regions north of the Mediterranean where the influence of Constantinople was great. Sermons about Christian life continued to be held. However, these were no longer based on Christology, but on ordinary human wisdom. It was still argued that Christians should avoid anger towards others (see e.g. Basilius, Adversus eos qui irascuntur, MPG 31:353-372). The reason for this, however, is no longer the

6.There is a debate about the authorship of the sermon. Bardenhewer (1914:600) considers the objections against its authenticity not convincing. For the present discourse the authorship is not relevant: it is anyway a sermon from the early Greek speaking church.

7.Alexander borrows from Melito of Sardis. Like Melito, Israel is portrayed as the perpetrator of the deeds against Jesus. The point, however, is not against the Jews, perpetrator of the deeds against Jesus. The point, however, is not against the Jews, the deeds of Israel is not punishment for the murder of God, but the healing and the life that Christ gives.

8.See examples in footnotes 4-6. communion in Christ who suffered guiltlessly, but that it is not wise to become angry. You demean yourself and suffer most through your emotions. Anger damages your human dignity. There are sermons of the great Basil, leading theologian in the days of the glorious triumph of Christianity, which come closer to Stoic discourse on ataraxia than to the early Christian wisdom of Christ. ${ }^{9}$

Now that the empire had become Christian, Christians had to be decent citizens and reliable subjects. The preaching of the church served this end. The themes might have been the same as two centuries before, but the context and the foundation had changed. Origenes ${ }^{10}$ and Chrysostomos ${ }^{11}$ shared the common view that one may not revolt against the emperor. Origenes based this on his Christian pacifism; Chrysostomos on the conviction that the emperor's authority is given by God. Therefore, the emperor had the right to completely destroy a riotous city. ${ }^{12}$ After revolts in Antioch, Chrysostomos took advantage of the fear of retribution by the emperor. There was not the faintest hint of doubt that the emperor had the right to do so. It was only due to his singular grace that he did not react with destruction, and that, of course, thanks to the mediation of the bishop (Chrysostomos, Homiliae XXI de Statuis ad populum Antiochenum habitae, MPG 49:211-223). Characteristic of this sermon is the remark that the riots should prompt reflection on their causes and how they could have been prevented (Chrysostomos, Homiliae XXI de Statuis ad populum Antiochenum habitae, 2.4, MPG 49:39). Chrysostomos found the blame to rest fully on the people of Antioch. Obviously, it did not occur to him that the policy of the emperor and his elite could have been the cause of the revolt. He (Chrysostomos, Homiliae XXI de Statuis ad populum Antiochenum habitae, 2.4ff., MPG 49:39ff.) is critical of wealth, but not of power. If Chrysostomos and his colleagues had envisaged the effects of power, perhaps the history of the eastern Byzantine empire and later, world history would have been very different. The oppression of the Byzantine emperors and their lack of empathy with the southern regions of their empire is a major factor in the rise of Islam.

Besides a different founding of Christian ethics, sermons characterised by a general worldview were remarkable. How is the world organised? What are the basic principles of the universe? How is contemporary physical science related to biblical texts on nature ${ }^{13}$ The Byzantine fathers from the end of the 4th century tried to develop a philosophia christiana, which they propagated in their sermons.

9.See, for example, the sermons of Basilius about anger (Adversus eos qui irascuntur), on envy (De invidia, MPG 31:371-386), on drunkenness (In ebriosos, MPG 31:443464), on humility (De humilitate, MPG 31:525-540).

10.Origenes (Contra Celsum, VIII.74v) argues that Christians pray for the emperor.

11.See especially his sermons (Chrysostomos, Homiliae XXI de Statuis ad populum Antiochenum habitae, MPG 49:15-222) after the demolishing of statues of the emperor during riots in Antioch.

12.Chrysostomos (Homiliae de Statuis, 2.2, MPG 49:35) compares the revolt with the earthquake which occurred shortly before this

13.See especially the sermons of Basilius (Hexaemeron, MPG 29:1-208\} and Gregorius of Nyssa (In hexaemeron explicatio apologetica, MPG 44:61-124) on Genesis 1. 
It could be argued that by doing so, Basil and Gregory resumed an old tradition of the 2nd century apologists. In one respect this is true: in both cases it was about a philosophia christiana. However, there was a fundamental difference: this was an alternative philosophy for a way of life totally different from the dominant culture, or a philosophy which had to provide a solid base for the ruling power, the present order, and the dominant culture. For the Cappadocians it was not a matter of: 'You are totally different, because you know Christ', but: 'You are fully in conformity, because we live in the Christian empire.'

There is a much lesser shift in the explicit Christological sermons. Sermons, which extol the exaltedness of Christ, continue even after Constantine, and not only on festivals, but also in series of homilies. In these sermons, the preachers came closer to their hearers, as in a sermon of Chrysostomos on Galatians 2:20: 'I no longer live, but Christ lives in $\mathrm{me}^{\prime}$. Paul does not say: 'I live for Christ', but something far greater: 'Christ lives in me'. Paul:

... does not say: 'who loved us' but 'who loved me' ... He shows that each of us ought to render as much thanks to Christ as though Christ had come for him alone. For God would not have withheld this gift even from one person. He has the same love for every individual as for the whole world. (Edwards 1999:33)

Sermons about Christ were at the heart of the preaching in the church - both before and after Constantine. However, there was a real difference whether Christ was thought of as the one who bears his cross in the midst of his persecuted followers, or as the Christos Pantokrator depicted on the dome of the Hagia Sophia, the court chapel of the Byzantine emperor.

\section{Origenes, Basilius and Chrysostomos on the expanse}

The difference in approach is best visible when sermons on the same texts are compared - most of all in a lectio continua, because then the preacher could display his hermeneutic paradigm, independent of a coincidental event or festival. As an example, three sermons on Genesis 1:7, regarding the waters above and under the expanse, are compared: one by Origenes (Homiliae in Genesin, I.2, MPG 12:147-149), one by Basilius the Great (Hexaemeron, MPG 29:1-208), and one by Chrysostomos (Homiliae in Genesin, 4, MPG 53:39-48).

Origenes immediately interprets the waters allegorically. The text is about the waters above and under the earth. God separated what is above and what is below, as he separated light and darkness. The water above the earth is the spiritual water where Christ is, and it is this water that we receive from Christ (with reference to Jn 7:38). The water under the earth is the water of the abyss - the place of demonic powers. Christians live on the line of separation. They are called to distinguish between these waters. God withdrew our dwelling place from the waters under the earth, where the demons and darkness rule, by making it dry. We therefore have to free our earthly life from the powers of darkness- the waters under the earth. Only then will we bear fruit through the spiritual waters of the grace of Christ.

Basil, in his sermon, enters into a discussion with the physicists of his day. How can the water stay on the dome of the sky? Would it not flow down along the dome? (Basilius, Hexaemeron, III.4, MPG 29:60). Aided by biblical data and contemporary physical models, Basil finds a solution which meets the requirements of Christian science.

Chrysostomos, in his turn, opts for yet another approach. First, he introduces the theme with a lengthy exposé about the use and preparation of sermons. From this, we can gather that the theme was not an easy subject for him. Subsequently, he clears away any misunderstanding about the number of heaven $\mathrm{s}^{14}$ by pointing out that in Hebrew 'heaven' is a plurale tantum (Chrysostomos, Homiliae in Genesin, 4, MPG 53:43).

Regarding the content, he mainly elaborates the theme aesthetically. It is good that God created order in the chaos, by separating light and darkness and creating the expanse. Chrysostomos (Homiliae in Genesin, 4, MPG 53:43) points to the beauty of the universe. Only this is visible to us. What greater beauty must lie above the expanse, in the domain of angels and seraphs, the domain of God (Chrysostomos, Homiliae in Genesin, 4, MPG 53:44). Our lives should be directed to this beauty.

The goal of these theologians differs greatly. Origenes wants to encourage his hearers to lead a life in Christ and bear fruit by withstanding the powers of evil. Basil explains how the world is a well-structured, ordered and balanced system. Chrysostomos wants to instil admiration and reverence for God's greatness in his hearers' way of life.

\section{Relevance for the present}

How relevant is the preaching of the early patres for preaching today? Firstly, we can learn that it is very important to have a clear paradigm for our proclamation. Such a paradigm prevents us from preaching randomly without a clear message, and from succumbing to any influence by the whim of the day.

Preaching in the church should also keep to the paradigm of the Early Church regarding the content: Jesus Christ is the Logos by which we interpret Scripture and organise our lives. This has consequences for the interpretation of the Old Testament. Early Christian interpretation did justice to the unity of the canon with the New Testament as the last redaction layer. While 21st-century Christians live in a different culture, they cannot apply the relation of sign and reality to such a detailed extent as Origenes did, but they cannot omit the principle: God's revelation is one, and his revelation is revelation in Christ. Consequently, it is not possible to apply Old Testament texts directly to our present-

14.On the contrary, Basilius (Hexaemeron, iil.3) extensively deals with the plural of heavens and the different characters of these heavens 
day society, or laws and promises for Israel to any national state today. These texts must always be interpreted through the lens of Christ whom we know from his life, death and resurrection.

A third point in these sermons of the fathers is their attention to events which happen to us and around us such as earthquakes, social upheaval, or war. To what extent do they provide texts which must be interpreted in light of God's actions? And if we regard them as such, interpretation requires extreme precision. In these cases, the paradigm of Christ crucified is essential. Critique and judgement can easily be applied incorrectly as was the case with Chrysostomos.

The shifts in the proclamation of the church in the 4th century should once again remind us to be careful not to provide a theological underpinning for a given situation, a dominant power, and a leading culture, while forgetting that Christians are strangers and resident aliens in the world. Are we critical enough?

To maintain these standards, it is necessary to preach explicitly Christological sermons in which the exaltedness of his grace and power is expressed. Indeed, Christ should be present in all preaching and its orientating paradigm. A dogmatic moment might also be helpful today, for the dogma alerts and prevents us from being uncritical and fashionable.

Finally, from the patres we can learn the importance of rhetoric. Regarding the content, they sometimes opposed the rhetorical tradition of their time, but methodically they used it continually, even if they did so alternatively. Rhetoric is not an aim in itself; it serves to bring the message across. 'It is not the beauty of speech ... but the reason of life'. ${ }^{15}$ Of course, most sermons will not have the rhetoric power of those sermons preserved by the tradition. Not everyone deserves the name Golden Mouth. Nevertheless, rhetorical training is necessary for a good preaching tradition. One should have a sound paradigm, a clear message, and a good method for passing this on to the hearers. If one of these is lacking, one runs the risk of becoming irrelevant and, in such circumstances, one can only save oneself by making popular statements that the hearers like and already know. A good preacher must know his hearers, and speak to their hearts, but do so with the strange message of the incomprehensible 15.Origenes, Homiliae in Exodum 1 (Heither 2008:20): "Non loquendi decor. sed ratio vivendi'.
God who let himself be crucified for our salvation so that, in communion with this God, we may display a different, strange way of living (Ad Diognetum 5).

\section{Acknowledgement Competing interest}

The author declares that no competing interest exists.

\section{Author's contributions}

I declare that I am the sole author of this research article.

\section{Ethical consideration}

This article followed all ethical standards for a research without direct contact with human or animal subjects.

\section{Funding information}

This research received no specific grant from any funding agency in the public, commercial or not-for-profit sectors.

\section{Data availability statement}

Date sharing is not applicable to this article as no new data were created or analysed in this study.

\section{Disclaimer}

The views and opinions expressed in this article are those of the author and do not reflect the official policy or position of any affiliated agency of the author.

\section{References}

Bardenhewer, O., 1914, Geschichte der altkirchliche literatur, vol. 2, Herdersche Verlagshandlung, Freiburg im Breisgau.

Edwards, M.J., 1999, Ancient Christian commentary on Scripture 8: Galatians, Ephesians, Philippians, InterVarsity Press, Downers Grove, IL.

Hawkins, J.B.H., 1886, Alexander of Alexandria: On the soul and body and the passion of the Lord, Ante-Nicene Fathers, vol. 6, Christian Literature Publishing, Buffalo, NY.

Heine, R.E., 2002, Origen: Homilies on Genesis and Exodus, The Catholic University of America Press, Washington, DC.

Heither, T., 2008, Predigten des Origenes zum Buch Exodus, Aschendorff, Münster.

Keith, J., 1896, The 'Second Epistle' of Saint Clement, Christian Literature Publishing Co., Buffalo, NY. (Ante-Nicene Fathers, vol. 9).

Lohse, B., 1958, Die Passa-Homilie des Bischofs Meliton von Sardes, Brill, Leiden. (Textus minores, 24). (Pseudo-) Methodius, Oratio in ramos palmarum, MPG, vol. 18, pp. 383-398.

Sieben, H.-J., 1991, Origenes: In Lucam homiliae. Homilien zum Lukasevangelium I, Herder, Freiburg. (Fontes Christiani 4.1).

Thierry, J.J., 1964, The Epistle to Diognetus, Brill, Leiden. (Textus Minores 33). 